\title{
The Co-production of Pilot Projects and Society
}

\begin{abstract}
This chapter discusses the shaping of pilot projects. Against a critique that such projects tend to be shaped top-down by powerful actors, our discussion notes how such projects are also shaped locally by materiality, culture, actors, interests and issues. Through this we show how projects end up looking very different from each other while enacting diverse socio-technical futures. We discuss three types of pilot projects: technologyoriented projects, geographically bound projects and national laboratories. We argue that pilot projects, in either form tend to mirror and amplify the interests of involved actors, and we proceed to discuss the potential politics of such projects. We do this by discussing processes of scaling up pilot projects, and through upscaling, shaping broader aspects of society. As these projects often have wide transformational ambitions, we conclude that a focus on who participates and who does not is central for future research.
\end{abstract}

Keywords Co-production $\bullet$ Interests $\bullet$ Pilot projects $\bullet$ Upscaling

\section{Introduction: Why Study Pilot Projects?}

One of our goals in this book is to develop a broad understanding of the roles that pilot and demonstration projects play in unfolding sustainability transitions in contemporary societies. Building on insights from science

(C) The Author(s) 2021 
and technology studies (STS) we have an interest in questions about how specific historical and social dynamics shape technologies (e.g. Williams and Edge 1996), and how technologies are constructed through the interpretations and work of different social groups (Pinch and Bijker 1984). Within such a perspective, pilot and demonstration projects that seek to advance smart grids or electro mobility, could be interpreted as distinct processes and products shaped by and embedded within the societies where they emerge. The situation is more complex, however, because neither society, nor technologies are static but change over time. One explanation for this is that technologies also contribute to shaping the very societies they become part of (e.g. Latour 1987). Hence, the pilot and demonstration projects we study are both products of and produces society-they are in other words co-produced (Jasanoff 2004).

Such an entry point to the study of pilot and demonstration projects in not only semantic word play. The perspective also underscores the importance of scrutinizing the activities within, as well as the outcomes, of such projects, beyond the notion of innovation journeys. Working from the assumption that new technologies are essential to future social orders, it becomes important to probe both how pilot projects emerge, and also which social orders they explicitly or implicitly promote. In asking such questions, we follow a long tradition of STS scholars working to understand the politics of technologies (Winner 1980; Sørensen 2004; Nahuis and Van Lente 2008).

Studying the shaping or construction of pilot projects is important, in part because it might shed light on whose politics such pilots enact. Critical readings of pilot projects within new and smart energy technologies tend to highlight their emergence as a top-down phenomenon (Throndsen 2017), shaped primarily by technology policies that stimulate experimentation in the interests of powerful actors. As an example, much experimentation within smart energy over the last 10-15 years can be described as emerging as a form of response to national or European policy agendas pushing to implement smart grids (e.g. Ballo 2015; Vesnic-Alujevic et al. 2016). European policy goals are also operationalized through priorities in funding bodies such as the Horizon 2020 (see Chap. 4). Such funding steers and shape innovation activities in distinct directions by circulating capital, ideas and technologies (see e.g. Skjølsvold et al. 2020; Rosenow and Kern 2017).

However, the image of the smart grid as emerging primarily top-down is not entirely clear-cut. As one zooms in on specific demonstration and 
pilot projects, these tend to be made up also by highly localized networks of actors who do not necessarily see themselves as responding to top-down technology push. Rather, they engage in issues that are constituted locally, and often rooted in quite specific problems, shaped by material conditions such as the local configuration of the electricity grid, distinct social issues or economic conditions (Skjølsvold and Ryghaug 2015). In this chapter we are interested in exploring how pilot and demonstration projects are constituted through diverse relations that do not necessarily sit well within the categories of bottom-up or top-down.

When zooming in on the techno-politics of pilot and demonstration projects related to renewable energy, smart grids and electromobility, we are confronted with an interesting duality: On the one hand, their politics are often quite explicit. If we mobilize the language from the multi-level perspective on socio-technical transitions as discussed in Chap. 1 (Geels 2002); they often seek to challenge, change or replace existing sociotechnical regimes. Following these explicit political agendas of many pilot and demonstration projects leads us towards an interest in how such projects, and the actors that take part, work to expand on, or to scale-up their proposed solutions (e.g. Naber et al. 2017; Ryghaug et al. 2019).

On the other hand, the delegation of the production of future social order to pilots, demonstrations and experiments also leads to discussions about their more implicit politics. Many scholars have argued that innovation activities in the name of sustainability, such as those discussed here, signals the emergence of a form of post-politics (Rosol et al. 2017) or anti-politics (Sadowski and Levenda 2020), where democratic processes are suspended at the expense of expert assessment and corporate interests. Others again, are more hopeful and highlight the political potential of such projects as sites that might produce new forms of democratic participation (Marres 2013, 2016). To us, there is no determinism attached to pilot and demonstration projects that leads to one or the other of these two positions. Instead, this tension signals the importance of studying the inner workings of such innovation activities, because so much is at stake within and around them: they are places where politics, participation and society might be steered in different directions.

The remainder of this chapter will be structured along the lines of the discussion sketched out above. First, we will discuss the societal shaping and emergence of pilot projects. While pilots might often appear small, they are characterized by the mobilization of a wide repertoire of resources and rationales that shape their content and activity. Building from this we 
move on to discuss these projects as political endeavours and how they in turn might shape societies; how they might scale up, what scaling up might entail, and the politics of pilot and demonstration projects more broadly.

\section{Exploring the Shaping of Pilot Projects}

Pilot and demonstration projects within energy and mobility are diverse and are developed by a highly diverging set of actor constellations with different rationales. In what follows, we will mobilize a sociologically oriented sensitivity from STS (e.g. Williams and Edge 1996; Pinch and Bijker 1984), as we discuss the characteristics of some typical forms of pilot projects. In our discussion, we move from strongly focused technologyoriented projects that are confined to relatively small spaces to pilots that are geographically much broader. We cover the following types of projects:

- The technology-oriented trial

- The geographically bound pilot

- The national laboratory

Through this exercise, we can explore pilots and demonstrations at different scales, but just as importantly, we probe their differences in terms of focus. While all pilot projects are socio-technical in nature, there are important differences in the ways that projects are set up: Some are primarily interested in harvesting technological or theoretical insights, while others more actively seek to explore relationships between technologies and social change. Between different types of projects, also the types of resources involved differ greatly, as do the types of interests and actor constellations involved in them. To us, this illustrates that it matters where and by whom pilot and demonstration projects are set up, because this is a key aspect of the politics that, in turn, become important in articulating future social order (Nahuis and Van Lente 2008). As we will discuss later in this book, this observation also places great responsibilities on the shoulders of all actors who fund, promote and enact such projects: the ways this type of innovation and research activities are configured might shape our collective futures in important ways. 


\section{Technology-Oriented Trials: From Laboratories to Regional Specificities}

Pilot and demonstration projects have become a distinct way of testing new solutions and instigating socio-technical change in areas in need of transformation or in areas where actors have ambitions for technological advancement and innovation. Smart grids and smart energy technologies are important examples, as areas where countless pilot and demonstration activities have been set up all over Europe and beyond during the last years. As an example, the database of smart grid projects across the European Union (EU) Member States names over 950 smart grid pilot studies conducted between 2010 and 2017 totalling around 5 billion Euros in investments (Gangale et al. 2017).

In short, smart grids entail augmenting electricity grids with software, sensors and new forms of controls, which are expected to result in much more active management of the resources flowing through the grid, on behalf of traditional energy producers, electricity grid operators and electricity consumers (e.g. Silvast et al. 2018; Goulden et al. 2014; Skjølsvold et al. 2015). These technologies are, on the one hand, expected to play a prominent role in enabling wide-scale integration of variable renewable energy production and to handle peak electricity demand in strained electricity grids. On the other hand, such technologies are also expected to enable the emergence of new types of market actors and market structures, who for example, capitalize on aggregating and commoditizing the choices of countless consumers and prosumers (e.g. Curtis et al. 2018).

These technologies have comprised a central element in energy transition roadmaps in places as diverse as the US, the UK and China over the last decade (Berker and Throndsen 2017), emphasizing our statement about smart grids being strongly promoted through top-down policies. Currently, the European Technology and Innovation Platform "Smart networks for energy transition" (SNET) argues in its "Vision 2050", that smart and digital technologies are one of the key building blocks of the energy transition. This platform is set up as an instrument to guide the research and innovation priorities of the European Commission, and as such, it represents an important voice both in terms of defining key policy priorities and in terms of funnelling financial resources into those priorities. The report highlights: 
In 2050, digitalisation facilitates services and the full integration of all kinds of energy systems: Several million households actively participate in realtime, automated demand response (electricity, heating and cooling) with connected appliances and equipment, in addition to the existing and emerging solutions for industry and commerce. (ETIP SNET 2018)

Further, the report goes on to highlight that: "Aggregation of smart charging technologies for electric vehicles, stationary batteries, heat pumps and power-to-gas provides controllable electricity loads". This is only one, of countless future smart energy visions, which provide direction for innovation, which in this case is also strongly linked to the provision of potential monetary and intellectual resources.

In a Norwegian setting, where we have conducted the main part of our empirical work, much inspiration for smart grid pilot and demonstration activities were triggered by a regulation passed by the Norwegian directorate of water resources and energy (NVE) in 2011. This regulation demanded that all households should have smart meters installed by 2019 . In Norwegian policy debates, this implementation has been considered a key stepping stone towards a blanket smart grid implementation, where the underlying rationale was based on socio-economic assumptions about smart meters enabling increased efficiency in electricity markets, rationality in grid operation, grid optimization and active consumption (Ballo 2015; Frøysnes 2014; Skjølsvold 2014). From the point of the authorities, the regulation was also framed as a potential trigger of innovation and industry development at the intersection of industries such as information and communication technology, electricity and construction.

\section{A Smart Grid Laboratory for the Purely Technical?}

The above paragraphs indicate that pilot and demonstration projects emerge in a broader context of national and international vision production, as well as regulations, policies and instruments that make resources available for trials with technologies that are thought to enable the materialization of such visions. In Norway, one could observe a surge of smart grid demonstration projects following the formulation of the regulation, where industry actors experimented with new arrangements based on smart electricity meters combined with other technologies under what they perceived to be relatively realistic conditions (Christensen et al. 2013; Fosso et al. 2014; Skjølsvold and Ryghaug 2015). 
Most of these trials and pilots have been strongly geared towards advancing technological innovation. In some instances, the activities have been framed by the involved actors as "purely technical". An example of this can be found in the Norwegian Smart Grid Laboratory, which is a physical set-up located on the campus of the Norwegian University of Science and Technology. The laboratory consists of a miniature physical power system. Much of the work done in the laboratory entails researchers and industry actors testing how new technologies respond under technically realistic, but highly controlled circumstances. The key goal, according to the management of the laboratory, is to "research and verify technology and functionality". In other instances, the smart grid laboratory has been framed as a system-oriented infrastructure for pilots and demo projects.

The production and shaping of this laboratory reflect Norwegian research priorities with respect to smart grids in the early $2010 \mathrm{~s}$. The laboratory was established with support of close to 30 million NOK (approximately $3 \mathrm{M}$ Euros) from the Norwegian Research Council and is institutionally anchored at the intersection of the largest technical university in Norway, and SINTEF, a large, industry-oriented research institution. Further, the establishment of the laboratory was strongly supported by dozens of actors in the electricity grid and production sector, who at the time were facing great uncertainty with respect to how a smart energy future would look. The laboratory enrolled actors from these sectors, in part by appealing to the costs of innovation and of rolling out technological solutions that subsequently fail during operation. Part of the rationale for building the laboratory was also its potential ability to attract further funding, for example, from bodies such as the Horizon 2020 and the Norwegian research council.

While involved actors tends to frame the goals of the laboratory narrowly in terms of developing and testing the functionality of new technologies, an examination of the laboratory with a socio-technical gaze illustrates that it in-fact has a much broader scope. It is a laboratory that mediates between industry needs and research interests, and its activities are shaped by a combination of political priorities both nationally and in the EU, future visions, academic interests, funding mechanisms and industry interests. During its operation, the laboratory has also been shaped further by the needs of the university, who have used the laboratory as a site of public and political engagement, welcoming a steady stream of delegations of energy policy makers and industry leaders that are guided 
through the facilities to illustrate the work done to materialize smart energy futures. Thus, we clearly see the way that the laboratory, which is supposedly a site of "the purely technical", has taken on the role as the place where the abstract idea of an energy transition can be put on material display to facilitate encounters between high level management of the university, policy makers and industry leaders, as well as between researchers and prospective societal partners. From an STS perspective, this is hardly surprising. While laboratories discursively are often praised as completely de-contextualized or "placeless" places (Kohler 2002), empirical studies of what goes on inside and around laboratories have illustrated the importance of their social, cultural and economic embedding (Latour and Woolgar 1979; Knorr-Cetina 1995). To us, the shaping of this laboratory as a key site of the energy transition in Norway is symptomatic of how a technical university and its epistemic culture, European funding mechanisms and national innovation policies have resulted in a narrow focus on technology development, which is often largely disinterested in how technologies become embedded in societies (Sørensen 2013).

The actors involved in this laboratory and the research, trials and developments within it, publicly reproduces the notion that technology development and testing are distinctly separate activities from making technologies work in society. As an information website for the laboratory highlights:

Topics such as market solutions, customer behavior and business plans are not covered in the lab but must be done in projects with customers involved that are managed by the energy and grid companies.

To us, this illustrates that the way pilot and demonstration projects are shaped, constructed and framed, are key to also shaping their politics. In this case, an overtly focus on technology has constituted several research and development communities, which if we mobilize the language of the multi-level perspective (Geels 2002) might represent a research regime and a selection environment that explicitly do not engage in social issues. Given the socio-technical complexities of energy transitions, this is problematic, and the consequences of such moves will be discussed later in this book. In what follows, we will concentrate on a set of technology-oriented pilot projects that precisely seeks to explore this relationship between new technologies and their use. 


\section{Technology Trials Outside the Laboratory}

Beyond the laboratory discussed above, several pilot projects emerged throughout Norway in the same period, all in the wake of the new national regulation that demanded smart meters to be rolled out across the country. Actors within the energy, electricity and building sector have traditionally been conservative, in the sense that they have favoured well proven concepts and materials at low costs, often developing new solutions and business models only when pushed in this direction through regulation (Ryghaug and Sørensen 2009). Hence, a policy-push explanation for the emergence of the pilots is tempting.

However, these first pilot and demonstration projects illustrate that a narrative of policy-push only reveals half the story. The regulation itself was relatively open-ended which meant that it left, in the hands of the grid companies, to make the most of the situation in terms of finding innovative and lucrative solutions that could benefit companies, users and society. In practice, these pilots and demonstration projects were shaped by a set of very diverse and local actor-constellations, which formulated a set of highly different issues and problems to address through smart energy piloting. Thus, smart grid pilots typically have been constructed by local actors across different sectors, who make the pilots parts of pre-existing local realities in quite different ways, while also mobilizing resources and interests from national, and international domains (Skjølsvold and Ryghaug 2015). We will give some examples below.

\section{The High-tech Neighbourhoods of the Smart Grid}

Smart energy pilot projects are constituted differently, and consequently, take on very different shapes. Consequently, pilot projects enable the articulation of quite different socio-technical realities. Two illustrative examples will help us see how this might unfold in practice. Our first example is in the south of Norway, a few kilometres outside of the small town, Arendal. Here, the interest in experimenting with smart energy technologies emerged from an alliance between a local electricity production company and actors in the building and property development industry. The initial background was a plan by a construction company to build a new neighbourhood of so-called "plus-houses". These houses should qualify as passive houses, but also be fully equipped with solar panels for prosumption. Geothermal boreholes and solar collectors produced hot 
water for space heating and showering, and for hot-fill washing machines and dishwashers. The houses were equipped with smart meters and smart home technology, and state of the art ventilation systems. Hence, almost every imaginable technology intended for a smart energy future was tried out. Direction to this work was provided by national and international research and innovation funding.

The projects outspoken aim was to produce technological and practical insights on how such a combination of technologies could work in practice. As such, their approach to innovation differed from that of the laboratory discussed above. Their innovation approach was described as a "living lab", emphasizing the importance of developing technologies that will function when they are to be implemented in society (Haugland forthcoming). When finished, the houses were to be sold on the ordinary retail market for a considerable premium price, targeting early adopters of new "green" technology. The plan for this neighbourhood was eventually becoming a real-life laboratory or a sort of natural experiment for the continued exploration of the relationship between new technologies and energy related practices.

The above story, in a rather straightforward way, illustrates how the interests of different actors' feed into project goals, thereby re-iterating the well-established point of STS that the involvement of different social groups influences technology design (Pinch and Bijker 1984). The involvement of a construction company that also develops and sells properties, resulted in an interest in exploring life in future homes, willingness to pay and new construction techniques. The involved energy companies were interested in how such high-tech living would influence the grid. Primarily, they were concerned with the combination of power intensive technologies and automation, and whether implementing many of these power consuming technologies at the same time and in the same place might lead to unintended consequences such as increased or new kinds of peak load problems.

While the primary interest of the trial was technological, it enabled the mobilization of a distinct focus on social aspects of the technologies tested such as technology-user experiences, thinking about how the new configurations of technologies would affect the identities of the neighbourhoods, and imagining who would want to live in these houses. In doing so, the actors who developed the neighbourhood, the engineers and housing developers, imagined what Strengers $(2013,2014)$ has named a "resource man"; an energy-interested optimizer who loves new gadgets. 
Further, the involved actors cultivated a certain interest in the day-to-day living with all these new technologies beyond how they would impact the grid.

This set the project apart from many smart grid trials, as much of the technical discourse surrounding smart grids often make jumps from abstract concepts like end-user flexibility to the idea of load-shifting or shaving peaks, without discussing the practices that make up electricity consumption (Katzeff and Wangel 2015). This demonstration project, on the contrary, attempted to address the production of flexibility, including the uncertainties that emerged in encounters between new technologies and their users. In sum, the socio-technical repertoire of such a pilot may be describes as being much broader than that of the smart grid laboratory. This outcome can in turn be attributed to a broader set of interests being involved in the formulation of what the smart grid might be, as demonstrated in this example. Our next example invokes an even broader anchoring of different interests and consequently, what may be the focus of a smart grids pilot.

\section{The Smart Grid Shaped by Healthcare Actors}

Our second pilot example is located in Stavanger, a city on the west coast of Norway. The city has been expanding rapidly for many years, mainly because it hosts many offshore industries involved in Norwegian oil and gas activities. This has generated a lot of wealth and many well-paid employment opportunities locally, resulting in a substantial population growth in the region and an increased pressure on the electricity grid of the area. Local grid operators and electricity producers thus faced significant challenges in terms of energy provision and security. Expanding the grid capacity, however, was not considered a viable option and local actors considered smart energy innovations to be a more viable path forward.

In doing so, the actors in this region approached the relationship between social and technological development in a more open way than the two cases we have discussed this far. The energy and grid company of the area first hosted a series of workshops, in which the goal was to identify social issues that could be addressed through the mobilization of 'smart'. As such, the involved actors quite explicitly formulated ideas about potential material political strategies. Several actors from local health care institutions participated in the workshops, which served not only as discussions about energy, but about regional development more broadly. A recurring 
theme which interested the healthcare organizations was what was perceived as a forthcoming demographic transition, in which the share of elderly people in the region would increase drastically. The initial workshops resulted in an alliance between traditional energy sector actors, ICT actors and actors within healthcare.

For the healthcare sector, smart energy technologies represented not only an opportunity to reduce energy consumption and shift loads, but a technological way to tackle their own peak load problems, in the form of crowded healthcare institutions. Together with the other actors, the idea of producing simple home control and automation technologies for the elderly, or for disabled persons as an integral element of the smart grid trial was forged. Such technologies, was the ambition, would make it easier for senior citizens and disabled persons to live in their own private homes, rather than in a healthcare facility. The prospects of transforming energy consumption patterns through using the same home control and automation technologies were seen as a possible added value.

This case illustrates once more that technological outcomes differ between sites, especially when the involved actor groups are divergent. In retrospect, one can be tempted to explain such outcomes by pointing to social and cultural factors such as local demographics and wealth. However, the example also points to the importance of the way such innovation processes are governed. Innovation outcomes do not only depend on where, by whom and when they are conducted. The practices and the work of the involved actors are essential (Callon 1984). In this last example we see how an active and open approach to innovating allowed for sensitizing of the involved actors to a potential link between so-called welfare technologies and smart grid technologies. This also resulted in an explicit criticism of many of the user representations mobilized in many other smart grid projects as this particular project were cast as a necessary move away from typical design processes where one was designing for resource man (Strengers 2013), and a quest to design technologies that everyone, even elderly, could and would use.

Another consequence of this move was that the sphere of influence of smart energy technology pilots expanded, and that their implicit politics would also potentially affect the world of healthcare. On the one hand, we can read this as a democratic opening for the participation of healthcare workers in energy transition activities: this actor group was now engaged in formulating new issues and new politics of energy transition. On the other hand, scholars have noted how welfare technologies often 
re-distribute health responsibilities from welfare states to other industries and from healthcare workers to the elderly themselves (e.g. Tøndel and Seibt 2019). With such and interpretation, this smart grid pilot project became enrolled in a form of politics which are also central for shaping the future of the healthcare sector and the logics of the welfare state more broadly. Either way, the example illustrates that as increasingly diverse sets of actors with various interests get involved in such innovation endeavours, the number and complexity of potential social questions increase.

In what follows, we will discuss pilot and demonstration projects of a different character and where the local or geographical characteristics have become even more prominent, namely pilots that embrace experimentation within a confined geographical area.

\section{Geographically Bound Pilots}

While the projects discussed above test technologies within a laboratory or within a neighbourhood consisting of a few houses, other pilot and demonstration projects focus on a particular geographical area, with the ambition of transforming the whole area over time. The most emblematic version of this is perhaps the city, which has for long been recognized as a site of experimental governance where civil society, commercial actors, municipalities and researchers work together through projects, often under the banner of smart cities. Castan Broto and Bulkeley (2013) identified no less than 627 urban climate change experiments across 100 cities globally, seeking to transform elements such as energy infrastructures, transportation and the built environment in cities. The politics of this development has been subject to criticism, which notes how smart cities have tended to promote a neoliberal agenda, celebrating entrepreneurship and privatizing ethics, while rejecting social justice as a legitimate goal of public policy (Morozov and Bria 2018). In such accounts, 'smart' is most often assumed to be a top-down transformative process.

Other scholars have noted that this is not the whole story. They have highlighted that smart cities can be both situated and purposive, mobilizing local resources and resources that circulate through global networks to shape individual projects and the city in diverse ways (Bulkeley et al. 2014). On the one hand, such differences in analysis might signal the different perspectives of analysts. On the other hand, however, it also highlights the importance of moving beyond emblematic labels such as "smart" to study how distinct innovation processes are shaped and enacted. To us, 
it highlights that who are involved in producing pilot and demonstration projects matters, and the fact that the outcomes and politics of such projects are not pre-determined. In the next section, we will look at another popular geographically bound site that is often preferred for experimenting with smart grids.

\section{The Island as an Example}

Cities are not the only geographical units that have become emblematic of pilot and demonstration projects rooted in smart energy technologies. Over the last years, many islands have taken on roles as eco-islands, smart islands or renewable islands. In such instances, the very islands involved in piloting serve as a key resource for the innovation activities. Islands tend to be relatively small and physically separate from mainland geographies, and therefore offer traits that resemble the laboratory. Grydehøj and Kelman (2017) have noted that such traits might allow innovators working on islands to gain quick, but credible results. Transforming the way energy is produced and consumed on an entire island serves as a material and practical illustration of how such a transformation might look in society, more broadly. Such islands, then, are often thought of, not only as technology test sites, but also as models or blueprints for how to achieve society-wide transition at a later stage (Skjølsvold et al. 2020).

Considering the above observations, pilot islands are not merely curious examples of fringe innovation activities, but potential spearheads in the promotion of new social orders rooted in smart energy technologies. As the examples discussed earlier in this chapter, demonstration activities on islands have been heavily promoted by the European Union and its innovation and research program Horizon 2020, which explicitly identifies the 2200 islands of Europe as laboratories and pipelines that are vital for realizing the continents energy transition. Islands, the research and innovation program suggests, are small, vulnerable and dependant on global energy commodity chains, but can be transformed and empowered though innovation, technology and competence provided through Horizon 2020 projects (European Commission 2020).

The narrative of this innovation policy undeniably reads as an agenda of powerful actors pushing technology and innovation from the top down. Island innovators tend to mobilize resources such as those made available through international, national and regional funding bodies in their endeavours, and through this, the activities on islands are shaped by 
national and international innovation policy. However, this narrative should also be nuanced, as many island pilot and demonstration projects are also articulated around local issues, and enacted by local actors.

The Danish island of Samsø can serve as an example. For more than two decades, this island has been heavily engaged in a series of energy transition and innovation projects, where renewable energy, smart energy and new transportation technologies have been central. Today, many of the activities are operationalized though a large research innovation project funded through the Horizon 2020. The actors involved in the project consist of energy producers and grid companies, ICT companies, as well as various researchers, primarily rooted in the technical sciences. The project's narrative of Samsø reflects the earlier discussed European innovation policy, highlighting that Samsø is small, has renewable resources and needs more efficient energy system management.

However, contemporary innovators on Samsø, also mobilize another element when highlighting why Samsø is an ideal site for smart grid innovation activities. This element is what some scholars call 'an imagined public' (Barnett et al. 2012; Ryghaug and Toftaker 2016; Solbu 2018), an ideal typical representation of a public produced by technology implementers and innovators. Actors who work to implement new technologies often conflate publics either to mean "consumers" of services (Cotton and Devine-Wright 2012) or "barriers" to implementation (Heidenreich 2015; Throndsen 2017), but on Samsø, the public is imagined differently. Here, innovators portray an enthusiastic and communally oriented public, which is understood to be an important enabler of innovation (Skjølsvold et al. 2020).

Compared with the three earlier cases discussed in this chapter, contemporary innovators on Samsø embrace what they perceive as a set of social characteristics of the place and cite these characteristics as essential to succeeding with their pilot. Papazu $(2016,2018)$ notes how this imagination of Samsø's public is a historical construct, rooted in events that unfolded from 1997 to 2007. During this decade, Samsø became largely self-sufficient with renewable energy through a much-discussed model of community building, public participation and shared ownership. In subsequent years, this narrative about Samsø's communal energy transition has become fixed to the point where it has taken on close to mythical proportions.

The transition story of Samsø has become exported and globalized. Papazu (2018) notes how this is problematic, because it obscures the 
many socio-material challenges that characterized the transition that unfolded on the Island. To us, the globalization of this narrative also serves to shed light on the shaping of contemporary pilot activities on Samsø. While European innovation policies shape activities on Sams $\varnothing$, part of Samsø's attraction for European funders is likely to also be shaped by its reputation as a communally oriented transition-island. In this way, the narrative becomes re-articulated and re-produced by new policy and funding body actors on a regular basis, which in turn re-establishes Samsø as a lucrative place for future pilot and demonstration activities.

Documents from contemporary pilot activities on Samsø, point towards a complex relationship between the way local interests and the interests of European policy, industry and research shapes these activities. At times, innovation activities on the island are highlighted to be concerned with the creation of local jobs, increasing the population and building new forms of community. At other times, the innovation activities are framed primarily as geared towards testing the future solutions of the European energy transition. Rather than seeing Samsø as the victim of top-down policies to materialize European visions of a smart, renewable and distributed energy future, we interpret this situation as a signal that the politics of pilot and demonstration projects are multiple.

While Papazu (2018) could be right in problematizing the way that publics on Samsø are imagined, we believe there is significant potential in mobilizing ideals about community and kinship as basis for smart energy innovations. Today, however, it is difficult to see how or if these ideals are reflected in the technologies currently tested on Samsø. Grydehøj and Kelman (2017) notes that islands who engage heavily in such innovation activities tends to mobilize terms such as "community" in order to masquerade that they engage in a form of conspicuous and highly competitive pursuit of technology oriented and dominated (sustainability) projects. Paradoxically, this would hardly be sustainable, in the sense that all islands cannot plausibly compete for and be high-tech frontrunner green islands. Further, it stands to reason that exporting and upscaling such a model offislands would be difficult.

In the above discussion we have moved from pilot projects undertaken in single laboratories, via trials in society to relatively large but geographically bound pilots, illustrated by the island as an example. In what follows, we will make a small conceptual leap, as we will discuss trials at a national scale as pilot projects. 


\section{The National Pilot-Project}

Trials at this size are quite rare, but not unheard of, and they offer a range of opportunities. Entrenching a pilot project deeply within society in this way means that they encounter all the various actors, organizations and technologies of that society. This means that such pilots will be less "controllable" than for example, earlier discussed examples of pilots in laboratories or pilots limited technology trials. Nevertheless, a country can represent a smaller, less-expensive and faster-responding trial than a broad effort to transform for example, global transport systems. In the past, Iceland has for instance been highlighted as an example of a country-size laboratory for the hydrogen economy (Park 2011). An important point is that such pilots might offer valuable opportunities not only for large-scale technology trials, but also for explorations of the impact of new forms of regulations and policies. In what follows, we will look more closely at one example, namely how one can understand the Norwegian electric vehicle (EV) transition as a national pilot project to develop, promote and implement electromobility, and what such an interpretation might entail.

\section{The Norwegian Case of Electromobility}

At the time of writing this book, auto manufacturers around the world are quickly embracing electro mobility and especially electric person cars, and several national and local markets for example, in California and Germany are growing rapidly. Nevertheless, Norway stands out in discussions around electromobility, because the country has promoted the emergence of EV markets in a systematic way for at least two decades, to the extent that that the country indeed, can be described as a national laboratory for electromobility.

The shaping of this laboratory can be described by distinguishing between two phases of development. If we mobilize the language from the multi-level perspective (see Chap. 1), the first period (1990-2009) can be described as a technology niche creation phase (Ryghaug and Skjølsvold 2019). Here, the political goal was primarily to nurture a Norwegian EV industry, and to create a domestic market for this industry. In the second period (2009-present), EV policies were legitimized through climate goals and aimed to create a market for EVs, regardless of where these EVs originated from (Ryghaug and Skjølsvold 2019). Today, the first phase tends to receive little appraisal, but in our view, this phase was crucial if we 
want to understand how Norway became the most advanced laboratory for EVs that it currently is if you compare the market share of electric vehicles to other countries across the world.

The first modern visions of Norway as a country producing electric vehicles emerged in the 1970s as a response to the OPEC oil embargo of 1973. Norway had vast hydropower resources. Developing an EV industry and challenging the fossil fuel-based mobility was therefore seen by a set of industrial pioneers as an ideal way of strengthening energy security in Norway. The notion was that while Norway at the time was poor in oil, it was rich in hydropower, and this should be reflected in the country's preferred mode of transport (Asphjell, Asphjell, and Kvisle 2013).

While these ideas did not come to fruition, it illustrates how an interest in developing new technology was shaped by a combination of international developments and local concerns. The activities also established a network of industrial actors who sustained the vision of Norway as an EV producing nation. This vision re-gained momentum in the early $1990 \mathrm{~s}$ primarily as a response to the enactment of the Zero Emission Vehicle (ZEV) legislation in California, which established a credit-system where car dealers had to earn credits from the sale of non-emission vehicles to legally be able to continue selling petrol cars (Hoogma et al. 2002). The scheme has later been dubbed "one of the most daring and controversial air quality policies ever adopted" (Collantes and Sperling 2008). Transition scholars have highlighted that the legislation was geared towards 'innovation pull', producing 'windows of opportunity' for battery electric vehicles (Kemp 2005), and has been deemed central to the development of EV friendly policies in other countries, such as Japan (Åhman 2006).

In Norway, the allure of this new potential market resulted in the emergence of a set of new industrial alliances, where Norwegian manufacturers, the hydropower industry and a series of other actors were able to mobilize national and international funding to produce a small, plastic chassis urban EV - a 'personal independent vehicle' called PIV (Hoogma et al. 2002; Buland 1994; Andersen 2013). For us, this illustrates that the shaping of pilots can be highly local, but that actors, interests and policies might also affect pilot activities at a vast distance. In turn, the opposite might also be true: through establishing a relatively large pilot market, the Norwegian context has arguably influenced the innovation work done by large international auto manufacturers.

During the early 1990s, the development and testing of these vehicles in Norway and the US took the form of several technology pilot projects, 
resembling those described earlier in this chapter. Building on a combination of financial resources from the EU, Norwegian industry and public funds, the goals of these pilots were, on the one hand, to verify technology and learn from real-life conditions, while, on the other hand, serving as a tool for public engagement. In many ways, these pilots can be interpreted as relatively successful, in the sense that they demonstrated the potential for EVs under cold conditions in Norway, as well as under quite hot and urbanized conditions in California. Just as important for the emergence of Norway as the EV-laboratory we see today, however, was the fact that these processes built substantial visions and expectations for a future large scale electromobility industry based in Norway, which was in the interest of several actors, including the hydropower industry (Skjølsvold and Ryghaug 2020). As a result, the Norwegian authorities throughout the 1990s gradually introduced policy incentives that were, on the one hand, meant to stimulate this industry, but which on the other hand, were meant to stimulate demand for the vehicles that this emerging industry was producing.

These developments led to the emergence of a pioneer niche market in Norway, in which vehicles such as the CityBee (later rebranded as Th!nk) and the Kewet found its niche role on Norwegian urban roads. These vehicles never became mainstream despite efforts to ramp up policies to stimulate their demand. Towards the mid-2000s, the Norwegian EV industry actors had more or less given up, and the Norwegian EV market was mainly served by international actors who considered the Norwegian EV benefits lucrative. This, however, was clearly not the end of the Norwegian EV laboratory. Rather, by this time, the climate issue had gained much higher prominence than it had during the 1990s, which changed the discourse in Norway substantially.

Since Norway was largely powered by renewables due to its vast hydropower energy supply, policy makers quickly turned their eyes towards transport in their quest to decarbonize, and electro mobility soon became one of the main strategies of decarbonization. Towards the end of the 2000s industry leaders like Mitsubishi, Peugeot, Citroën and Nissan began launching new flagship EV models and Norwegian car dealers immediately began importing them. The Norwegian EV market especially boomed after the introduction of Mitsubishi i-MiEV in 2010 and the Nissan LEAF in 2011 (Lorentzen et al. 2017). 
Since 2009, Norway has actively embraced and been outspoken about the country's role as an EV policy laboratory, in which new policies locally and nationally have been experimented heavily with. This has been a combination of policies intended to stimulate increased demand for EVs, locally and nationally, and policies to enable an easy transition from driving fossil fuelled cars to electric cars. This package of policies has included free or reduced cost on ferries and VAT exemption for car leasing. Further, a governmental support scheme for public charging infrastructure was implemented in the years 2009-2010, followed by public coordination of fast charging infrastructure and charging facility developments across the country. Small municipalities with few chargers can today seek financial support, and the goal is to have fast charging stations around every $50 \mathrm{~km}$ on Norwegian roads. The network of chargers throughout the country is probably a culturally important safety-net which mitigate what is commonly referred to as range anxiety (Noel et al. 2019) and is something that contribute to the further growing of the EV market. Several municipalities and cities have also followed Oslo in allowing EVs to drive in bus lanes.

Through the activities discussed above, Norway has effectively become a sort of large-scale pilot project that explores the societal consequences of implementing electromobility earlier than comparable countries. As the above discussion have alluded to, this laboratory role was shaped by a long and cumbersome process, which includes some distinctly local interests such as those rooted in hydropower and national industrial development, international research and development networks and consortia, as well as, later, the pressure to reduce climate emissions. As a national pilot, the goals are also much more diverse, than for example the goals of a pilot in a physical laboratory. In a national project, one tests technology in a reallife setting. In addition, one also tests the effects of policies, behaviours and practices at large scale, as well as the links between developments in, until now, quite separately working sectors such as energy and transport. An important example is experimenting on the way that electromobility is and might impact the electricity grid, the operation of the grid, as well as innovations in managing and developing the electricity grid (see Chap. 3 for an example). 


\section{The Significance of How Demonstration Projects Are SHAPED}

In the above, we have produced a set of accounts that illustrates how pilot and demonstration projects are shaped by societal processes. We have worked from assumptions derived from decades of STS-scholarship, which highlights how historical, social and cultural dimensions as well as the interests of involved actors shape technologies (e.g. Pinch and Bijker 1984). Technologies, in turn, shape and produce future societal conditions, indicating that technology and society co-produce each other (Jasanoff 2004). To us, this suggests that technologies take on an oftenunappreciated political significance in shaping future social order (Winner 1980), and that how, by whom and where technologies are made is essential for the shaping of these future social orders.

The discussions above suggest that pilots are important within energy transition activities, and within the shaping of future societies. Therefore, it is central to understand who the actors involved are, which agendas they advance and legitimate and the processes through which such advancement and legitimation occurs. While there are significant differences between the projects we have discussed, there are also a series of similarities, which to us points towards the importance of thinking systematically about how to shape and produce pilot and demonstration projects differently in the future.

All the projects discussed here starts from the assumption that technologies are the key vehicles through which societies will reach their energy and climate ambitions. The projects reflect on the relationship between their innovation activities and social aspects to various degrees, but they all mobilize a rather narrow understanding of the potential ways their activities and technologies relate to the social world. Insofar, we have also seen the social world represented primarily as technology users or as supporters of unfolding innovation activities. To us, this is reflective of the actors and processes that shape the types of pilot and demonstration projects that we have probed here. In this way, the pilot projects can be said to serve as a mirror, projecting back the interests of the involved actors in the form of a technologically oriented image of societal change to the world around.

While the projects are technology oriented, they mobilize these technologies to address different types of issues. Some of these issues, such as the need to balance supply and demand in energy systems are generic and 
related to dynamics of the energy transition. Others, such as demographic transitions and related challenges in healthcare are local, more specific and points towards the potential of broader social engagement within and around pilot projects. This dual focus is reflective of the resources and actors that tend to be involved. On the one hand, projects tend to involve international funding, large national and international actors within energy, ICT and research, but on the other hand, often also local interests and locally invested actors. In such constellations, we see the mobilization of local issues as hopeful, because it points towards the possibility of broader social and political transformative repertoires enacted through technology (see e.g. Marres 2016; Ryghaug et al. 2018). In the projects discussed above, however, this potential largely remains dormant. While the established pilot projects reflect the local conditions and involved interests, the imagination with respect to the role of the social and political is limited, and mainly operationalized as technology use or consumption. This signals a narrow agenda within such pilots, and to us opens a question if the types of constellations we have discussed above will be able to deliver radical transformations or mainly advance agendas of incremental change.

Seen all together, our discussions on "the origin stories" about how different pilot projects came into being and how they were produced, sheds light not only on discrete innovation practices, but illustrate a key function of pilots beyond testing and deployment of new technologies. In this chapter, we have noted how pilots serve to "mirror" the interests that produce them. This metaphor, however, is too weak because pilots not only reflect, but also amplify the interests, resources and rationalities that are built into them. As a social and material performance, pilot projects signal what Mike Michael (2000) has described as the temporal proximity of futures rooted in these pilots. In other words, pilot projects signal that the world will soon be changing in their image.

This points to the importance of re-thinking how pilot and demonstration projects are currently produced. Given the need to radically transform our collective relationships to energy and transport, we believe it is worth questioning if the types of projects that we discuss here ask the right questions, or if one could envision innovation done differently. Schot and Steinmueller (2018) question the contemporary quest for technological innovation as a solution to the sustainability challenge, and Marres (2016) notes that piloting or experimenting for sustainability can be done with roots in social questions, as opposed to those primarily rooted in 
technology. We have also flagged hopefulness on behalf of the political potential of pilot projects earlier in this chapter. On the one hand, the responsibility for change lies in the hands of project operators. On the other hand, our discussion also suggests that there is a broader question to be raised here, concerning research and innovation policy. The origin stories discussed above do not appear in an epistemic vacuum but follows broader logics of how change and transition is promoted in contemporary research and innovation efforts in Europe. We will return to the issue of innovation policy in Chap. 4.

\section{Beyond Pilots: Understanding Pilot Projects in Broader Energy and Sustainability Transitions}

So far, we have been concerned with the construction of pilot and demonstration projects. Now, we will turn to what such projects do once they have been established, and the potential relationships between pilot projects and the world around. Pilots situate new technologies in society (Forlano 2019), providing a potential socio-technical model for how to organize activities in ways that are considered more sustainable or more beneficial than contemporary practice. However, their reach is often limited. Above we have discussed examples rooted in the laboratory, a few houses in a neighbourhood, islands and a nation. A key question for innovators is how such limited pilot activities can be expanded or scaled up to transform broader elements of society (see e.g. Naber et al. 2017; Ryghaug et al. 2019). In our case, these questions first translate into an interest in the processes and work that makes such projects grow, and second, into a concluding discussion on the potential politics that are advanced as such projects become increasingly important for the direction of societal development.

\section{Upscaling and Accelerating Energy Transitions Through Pilot Projects?}

In current debates on sustainability transitions, pilot projects and experiments have been pointed to as central drivers in the acceleration of transitions (Von Wirth et al. 2017; see Chap. 1 for a discussion on the acceleration phase of transitions). The question of how pilot projects and experiments can 'scale up' has therefore been highlighted as a key research challenge 
for scholars working on sustainability transitions over the coming years (Köhler et al. 2019).

Within STS, processes that bear resemblance to what transition scholars call up-scaling have been conducted for decades. The most famous example is perhaps Latour's (1993) account of how Louis Pasteur transformed his laboratory trials on Anthrax vaccines into a successful program for the whole of France, thus stopping regular mass death of livestock in the country. In Latour's interpretation, this work consisted of Pasteur conducting a series of stagings, in which farmers were enrolled and required to re-produce laboratory-like conditions in their farms through strict measures of hygiene and cleanliness. Following this, trials were conducted insitu on farms, both as a real-life test, and as demonstrations of the vaccine's feasibility. This means that up-scaling, in this case, entailed expanding the laboratory into new realms of society through partnering with farmers, and convincing these farmers to adopt the practices of the laboratory. Beyond this, Pasteur also enrolled the mass media, which on different occasions produced vivid accounts of the vaccination success. For Latour, then, the successful upscaling of Pasteur's laboratory experiment primarily hinges on the production of a public (in this case the farmers) who shares the interests of the innovator, who in Latour's narrative becomes just as much a social and political entrepreneur as a microbiologist.

The process where innovators and entrepreneurs seeks to attract interest and support for a particular innovation by means of persuasion, negotiation and aligning with interests of other actors, is often described as translation (Callon 1984; Latour 1987). Re-read in light of sustainability transition challenges, this model of innovation is a way to describe processes of up-scaling and acceleration of transitions. Translation describes the processes of how certain actors might ascribe new roles to other actors, and highlights that the route towards technological success lies in building strong actor-networks around new artefacts. Building the network consist of developing different scenarios and enrolling new actors in the enactment of such scenarios (Latour 1987). When a scenario is developed, the scenario is translated to appeal to what is believed to be the relevant actors' needs and wishes. Translation has been described as a four stage process that emphasizes the displacements and transformations of goals, interests, and devices, human beings and inscriptions happening in four 'moments' or phases with four components: problematization, interessement, enrolment and mobilization (Callon 1984; Hess 1997). 
Problematization signifies the process of defining the issue in a way so that other actors accept one's definition of the problem. They gradually come to accept one's knowledge claims or technology as an obligatory point of passage, that is, as a necessary means to solve their problem. Interessement refers to imposing and stabilising the roles of the other actors defined by one's problematization. In other words, the process of translating the images and concerns from one world into that of another, and then disciplining or maintaining that translation in order to stabilise a powerful network, thus "locking" other actors into the roles that were proposed for them in the actor's programme for resolving that problem. The result of interessement is the enrolment where actors or entities are attached to the network in interrelated roles. Finally, mobilization is ensuring that supposed spokespersons for relevant collective entities are properly representative of all members of the network that are acting as a single agent, representatives to act as spokesperson of other entities (Callon 1984). From Latour's work, enrolment does not only mean involving people, but also nature and technologies.

Within sustainability transition studies, the last years have seen several examples of scholars exploring similar processes around pilot and demonstration projects dealing with new energy and mobility technologies. Here, however, the focus on translation tends to be implicit, while the literature rather works to develop typologies which point to ideal-typical patterns of development, or of mechanisms, that result in the growth of projects.

Naber et al. (2017) provides one example, as they distinguish between four patterns of upscaling. Growing, describes a continued process of experimentation, through which more actors become participants, or market demand increases. This might enable growth either in the size of projects, or in the types of activities involved. Replication points to the use of key concepts from one trial in other locations. Accumulation indicates the production of links between pilots and networks of pilots. Finally, transformation points to changes that occur as such projects shape wider institutional configurations.

Frantzeskaki et al. (2017) provide a similar line of reasoning and develop a framework for understanding the different ways that urban transition initiatives can accelerate transitions. This framework describes five mechanisms that may contribute to acceleration. These five mechanisms are: Upscaling, which entails growing the number of members, supporters or users of a single transition initiative; Replicating, which is the take up of 
new ways of doing, organizing and thinking of one transition initiative by another transition initiative; Partnering, which is the pooling and/or complementing of resources, competences, and capacities in order to exploit synergies between initiatives; Instrumentalising, which entails tapping into and capitalizing on opportunities provided by the multi-level governance context of the city-region; and finally, Embedding, which describes the alignment of old and new ways of doing, organizing and thinking in order to integrate transition initiatives into city-regional governance patterns.

We find these accounts useful, because they give some hints about what up-scaling might entail in practice. However, we also question whether the neutrality of terms like "patterns" and "mechanisms" really captures the dynamics of up-scaling. Our discussion on the genesis of pilot and demonstration projects suggests that the projects reflect and amplify the interests of those who produce them. STS scholars such as Bruno Latour (1993) and Michael Callon (1984) have pointed to the social and political aspects of spreading ideas and technologies, which points to a much more active role on behalf of certain actors in advancing their ideas, and that an element of this is also persuading others who might contest the technology at hand (e.g. Sørensen et al. 2018). The focus on the active elements, for example, in the form of translation when looking at the up-scaling of pilot and demonstration projects also makes the political character of this work more explicit: ultimately, up-scaling entails actively working to promote one vision of future socio-technical order at the expense of others. In what follows, we will look at one example of how such a process might look in practice.

\section{How Pilots Scale Up: An Example}

Pilot projects often remain standalone learning sites where little knowledge travels beyond the project and the involved participants. This means that many projects bring little change to the broader systems they intend to transform (Heiskanen et al. 2017). Naber et al. (2017) and Frantzeskaki et al. (2017) provide useful starting points for contemplating how movement beyond individual trials might, and do, unfold. From the early days of STS (e.g. Callon 1984; Latour 1987), we are also sensitized to the political and social entrepreneurship that might enable such processes in action. The example we now zoom in on is a pilot project that is primarily pushed forward and conducted by one company. This company is one of the largest grocery wholesalers in Norway. The company sells and 
distributes groceries to 1700 stores and restaurants, a task it has conducted using traditionally fuel intensive delivery trucks.

In contemporary news media coverage and public discourse, this company clearly stands out as the main character in a narrative about an ambitious pilot project that combines large-scale production of solar power with electrolysis to produce hydrogen fuel cells in a quest to decarbonize its large fleet of heavy trucks. Their role as such, however, was not always clear-cut, because the initial phases of this pilot were not set-up by the company. Rather, the company was arguably the main public for a trial envisioned by other actors, primarily a group of technology developers and scientists who had been researching and advocating the benefits of the hydrogen economy for more than a decade.

This group had developed a small fuel cell, which was intended to power only the lifts that distribution trucks use when loading and unloading goods. As heavy users of such trucks with a reputation for seeking out low-carbon technology, the company constituted what the scientists imagined as ideal users of this fuel cell. The problem was that the company was not really interested, as they thought hydrogen was the fuel of the future, but not the present. Further, they were not convinced by the merits of replacing the lift battery with an alternative. Hence, to stretch the activities of the scientists beyond the laboratory, the company needed convincing. This illustrates that these scientists recognized the strength of a pilot project. Hydrogen has always been the fuel of the future in Norway (Kårstein 2008), but with few pilot projects to learn from. A pilot could materialize the vision (Engels and Münch 2015), positioning the hydrogen economy temporally closer to our present time (see. e.g. Michael 2000).

Faced with this challenge, the scientists attempted another strategy, namely by proposing a small project to measure emissions from urban delivery trucks. The company accepted to be part of this project, and the results indicated that on a typical urban delivery route, trucks spent more time idling with the engine running than driving around, because the diesel engine was used to power the electrical lift battery. With these results in hand, the grocery wholesaler became an interested actor, who envisioned both economic and environmental benefits from replacing the batteries with a small hydrogen fuel cells to power the lift used when loading and unloading goods of their distribution trucks. They agreed to retrofit a few trucks. This can be interpreted as an initial form of upscaling in the form of what Naber et al. (2017) calls growing. The process of achieving this growth echoes Latours (1993) analysis of Pasteur, where 
"interessement" and "enrolment" is achieved through extending the laboratory to new sites in society.

Technically, the initial trials were a success, and the company was able to document substantial emissions reductions, due to the reduced need for idling. Just as importantly, this small-scale pilot transformed the management of the grocery wholesaler to hydrogen enthusiasts, in a way reminiscent of Callon's (1984) notions of translation. The company was now not only using the technology from the initial trial but were actively producing new visions for the hydrogen economy in Norway. A step towards this goal would be their own pathway towards a fully hydrogen powered fleet of trucks. Hence, this meagre technology trial yielded lessons that were now transforming the foundations of this company. Frantzeskaki et al. (2017) calls this embedding, while with the words of Naber et al. (2017) this was arguably transformative, in the sense that this initial pilot contributed to transforming what Geels and Schot (2007) have described as the grammar, or the rules of the game for this company.

These developments unfolded at the same time as the company was conducting a much simpler technology project, namely investing in a large solar power park which was to be placed at the rooftop of one of the grocery wholesalers storage facilities. In certain periods of the day and season, this setup produced a surplus of electricity on their site. Coupled with visions about hydrogen futures, the idea of using this renewable energy source to produce hydrogen through electrolysis soon emerged through discussions with the earlier mentioned scientists and technology developers.

Following this, the goal was to establish a new pilot project which aimed to transform the way this grocery wholesaler transported goods. The vision was that the vehicles would be entirely fuelled by hydrogen produced on-site. This is symptomatic of a form of institutional change that has been identified in the German energy transition, where increased interaction between the renewable energy sector, the transportation sector and ICT actors have created what Canzler et al. (2017) have described as a new strategic action field which opens for new and sometimes radical forms of innovation. A challenge, however, was that acquiring heavy duty hydrogen trucks was difficult: as far as the involved actors knew, such trucks did not exist.

The company and the scientists set out to partner with a large European truck manufacturer but received only lukewarm interest. The car manufacturing industry has been described as a conservative regime that has slowly and reluctantly reoriented towards implementing new and more 
sustainable fuels and technologies (e.g. Penna and Geels 2015). While the grocery wholesaler is a relatively large company in Norwegian terms, it was a small international player, and struggled to find anyone willing to take part in what was perceived as a high-risk endeavour. Through intense lobbying together with the scientists, however, the company was able to convince their existing car manufacturer, to deliver three 27-tonne trucks, to be experimentally developed by the supplier together with a project group consisting of people from the grocery wholesaler and associated scientists. This move can be said to represent a new form of growth within this project, perhaps best described in terms of what Frantzeskaki et al. (2017) call partnering, or in Naber et al.'s (2017) terms, accumulation, signalling that there were now even more elements drawn into this conglomerate of activities.

Following this, the company added several new elements to the pilot. They invested in an off-the-shelf hydrogen production facility which they installed on-site to produce hydrogen from solar power, as well as a fleet of hydrogen powered forklifts to be used within their own storage facility. These activities arguably resulted in what Naber et al. (2017) call transformation: The grocery wholesalers' role in the energy and transport systems was changed drastically. From being a traditional wholesaler that stores and delivers groceries around the region, they were now a large electricity producer, a producer of hydrogen fuel cells, and a co-developer of a new type of delivery truck. Thus, from the initial small beginnings within a laboratory and shifting the engine on the lifts of a few trucks, this is clearly a story of up-scaling. Still, however, the technologies and innovation processes of this single pilot only encompass a few dedicated actors. But the efforts to upscale go beyond the story of this company.

Currently, the grocery wholesaler arguably pursues three key strategies to produce better framework conditions for the innovations they have been part of developing and testing. The first consists of continued growth within their own organization, primarily through expanding the fleet of hydrogen powered trucks. In doing this, they also model future hydrogen demand, to illustrate to others that they will be unable to meet their own demand after 2023. This brings us to the second strategy, which can be characterized as a form of translative networking or partnering, where they attempt to persuade actors within renewable energy production such as wind farms to produce hydrogen. Finally, the company's third strategy consists of politicizing their own pilot activities and their own engagement for hydrogen as an essential element in the future socio-technical order of 
Norway. They lobby municipalities in order to increase the importance of environmental aspects in procurement processes. Further, they regularly seek to influence annual state budgets, policies and authorities responsible for providing the framework conditions and supporting activities to cut emissions and promote more sustainable transportation. They actively target political parties and national strategy processes, working to convince others that hydrogen should have priority over competing technology options.

It is difficult to assess the success of all the activities described above, but this is also beside our point. Instead, the activities illustrate how the work and dynamics of constant growth and upscaling, within and around a pilot project can unfold. All this work has been highly visible in parts of the Norwegian public debate. It has attracted significant attention from political actors, and the Norwegian prime minister has been photographed in front of this grocery wholesaler's hydrogen trucks, proclaiming that this project heralds no less than the start of a new era. From meagre beginnings where engineers were seeking out application areas for testing and experimenting with a small hydrogen fuel cell and with the goal of powering a small vehicle as a trial, the actors involved in this pilot project now seek to transform their own practical, technological and institutional surroundings in such a way that these surroundings in turn might become precisely what enables the project and this version of the hydrogen economy to grow further.

\section{Implications for the Literature on Upscaling: From Patterns and Mechanisms to Strategies}

Within the socio-technical sustainability transitions literature, there has been a tendency to describe processes of up-scaling in relatively neutral terms such as patterns (Naber et al. 2017) or mechanisms (Frantzeskaki et al. 2017). This is a tempting move, because it provides hopes of generalizability, which in turn opens for learning across cases. We sympathize with this ambition, but working from an STS perspective, we also want to problematize this. The case discussed above illustrates that this apparent neutrality might conceal the political character of enacted agency within processes up-scaling. Our case indicates that in all observed instances, upscaling was challenging, and that other outcomes were also possible. In the spirit of deriving lessons from case studies, we therefore want to point 
to two strategies that we see as essential in work to scale up from pilot and demonstration projects.

- Persuasion: a key strategy to achieve several of Naber et al.'s (2017) and Frantzeskaki et al.'s (2017) patterns and mechanisms is persuasion. This signals that pilot and demonstration projects are potentially contestable spaces. They represent a potential socio-technical order, but there are many such orders out there, including the dominant ones that pilots often seek to destabilize. Thus, partnering, growth, replication and accumulation are not only patterns or mechanisms, or necessarily the result of peaceful alignment and deliberation, but outcomes of successful acts of persuasion.

- Politicization: a key element of Naber et al.'s (2017) framework is the pattern of transformation, whereby a pilot project transforms wider institutional conditions. Politicizing is an explicit way of problematizing and challenging current institutional configurations based on ongoing innovation activities. It signals broad social and political ambitions beyond technology deployment, and explicitly targets actors and processes that are outside the unfolding pilot activity as such.

These two points are suggestive of the potential of mobilizing STS in both the study of sustainability transitions, and as inspiration for practical strategies within such transitions. While perspectives rooted in the MLP and related frameworks tends to highlight the need to produce shared visions and directionality, our narrative here also point towards the importance of agonism and contestation, and that in light of this, translation becomes a key mode of working.

\section{Concluding Discussion: Towards an Appreciation of the Political Character of Pilots and Demonstration Projects}

The discussions in this chapter have illustrated how pilot and demonstration projects are shaped and produced, as well as how actors work to scaleup such pilots. We have argued that pilot projects embody and enact desires for future socio-technical order. Through these discussions, we have come to see how pilots tend to reflect, legitimate and amplify the 
interests and resources that shape them. Further, we have seen that processes of scaling up such projects are characterized by persuasion and politicization. Through this, we have come to see pilots as sites where future possibilities become materialized, where transitions and transformations are enacted.

With this as a backdrop pilot projects within energy and mobility must be considered political sites, or as Marres (2016) calls them, in-between sites, where normal obligations and relations may cease to exist. Within such in-between sites one can, according to Marres, explore (a) technologies, through implementing unproven concepts, (b) politics, by suspending established rules of public accountability and (c) society, by trying to establish new ways of doing things (Ibid., p. 4). Seen through such a lens, some types of pilot projects might take the form of a materialized imaginary (Engels and Münch 2015), in the sense that they not only render visible a potential technological future, but also a desirable future society around and intertwined with the technology.

This creates a form of tension. On the one hand, it might result in pilot projects being very effective tools of governance and innovation (Marres 2016). They can be productive in terms of introducing new technologies and new socio-technical trajectories and futures. The examples we have discussed in this chapter to a large degree confirms this. However, it is less clear if these pilot and demonstration projects are effective in terms of fulfilling other societal and social needs and how this mode of governance through pilot projects might affect how we steer societies more broadly. For us, these observations lead to an interest in a set of aspects that characterize pilot projects as sites of governance or as sites of societal steering.

First, the discussions in this chapter have illustrated that developing and conducting pilot and demonstration projects tends to re-distribute the legitimacy of actors within a specific domain. One obvious example of this is the increasing importance of ICT competence in transforming domains such as energy and mobility.

This reflects the way pilot projects often combine a desire for highly specialized technological outcomes with broad and complex social change. Thus, pilot projects need combinations of very specific competence just to work technologically, while they often need other actors to provide the societal vision within and around which these technological solutions are intended to work. Hence, pilots not only provide legitimacy to new sets of actors, but also to new sets of visions, ideas and goals for future society. As we have seen in this chapter, the content of such visions might differ 
radically: Visions and expectations might range from visions of a convenient and simpler everyday life for the elderly, to more prosperous islandlife and multi-and cross-sectoral visions for the future hydrogen society. Across such visions, there tend to be new roles for technology users, customers or citizens, new forms of business or new modes of organizations, which in sum serve to re-shape many aspects of society within or around pilot projects.

This means that the potential political effects of pilot projects stretch far beyond the boundaries of such projects and allows actors that innovate within energy and transport to assume the power to transform aspects of society that at a first glance might appear out of their reach. This is one of the reasons why it is essential to probe participation within and around emerging technologies and such projects, and also why we dedicate an entire chapter in this book to this theme where we ask if pilot projects represent a shift away from democratic decision-making in society, and if so- how should we understand this development? How should the development be governed?

Frantzeskaki et al. (2017) note that pilot projects and other transition initiatives are key vehicles to accelerate sustainability transitions, in other words, to increase the speed of technology deployment, diffusion and thereby the replacement of existing and fossil-intensive socio-technical systems. According to the sociologist Hartmut Rosa (2013) acceleration is one of the key traits of late modern societies. In his analysis, acceleration is a generic processual trait that has fundamentally altered the way political decision making has been conducted in modernity. In a time that values acceleration beyond other imperatives, he argues, democratic decision making is too slow, and serves as a "brake" to further acceleration.

Rather than democratic decision making, he highlights that decisions with respect to collective ethics and future organization for realizing such ethics are privatized, that key societal decisions are increasingly made based on economic evaluations and that key disputes are settled through judicial processes rather than democratic deliberation. This amounts to a description of a time characterized by a post-political situation. Some readings of governance rooted in pilot and demonstration projects have highlighted that such projects can be understood to represent precisely this: That such projects "intentionally sidestep the tensions between bottom-up and top-down approaches to innovation in favour of lateral partnerships" (Evans and Karvonen 2011), and that they therefore provide ample opportunities to remove control from government, to cede it to 
private interests, and to understand climate change primarily as a business opportunity "in the guise of helping society at large" (Evans and Karvonen 2011).

Such a sinister reading of the potential political role of pilot projects, however, is countered by accounts that highlight how they might come to occupy more of an intermediary space, where they allow for new types of negotiations and deliberations between technology developers and potentially implicated actors. Here, pilot projects might serve to open technology driven processes to wider and more diverse forms of democratic participation, rooted in diverse and often local issues. This means that innovation through such processes might also serve to challenge established structures, and though this, bring about new configurations which would otherwise not emerge. Evans and Karvonen (2011) have concluded that the politics of such projects are "up for grabs". This is a reading we sympathize with. In our view the politics of such projects are always up for grabs, because what they will be, depends on the specific configurations that shape the process by which they are established, in which resources are mobilized, as well as by the way such projects are positioned vis-à-vis broader societal processes. In the next chapter, we will follow up on this by more explicitly probing pilots as potential sites of participation.

\section{REFERENCES}

Åhman, M. (2006). Government policy and the development of electric vehicles in Japan. Energy Policy 34(4), 433-443.

Andersen, O. (2013). Towards the Use of Electric Cars. In Unintended Consequences of Renewable Energy (pp. 71-80). London: Springer.

Asphjell, A., Asphjell, Ø., \& Kvisle, H. (2013). Elbil på Norsk. Oslo: Transnova. Ballo, I. F. (2015). Imagining energy futures: Sociotechnical imaginaries of the future Smart Grid in Norway. Energy Research \& Social Science, 9, 9-20.

Barnett, J., Burningham, K., Walker, G., \& Cass, N. (2012). Imagined publics and engagement around renewable energy technologies in the UK. Public Understanding of Science, 21(1), 36-50.

Berker, T., \& Throndsen, W. (2017). Planning story lines in smart grid road maps (2010-2014): Three types of maps for coordinated time travel. Journal of Environmental Policy \& Planning, 19(2), 214-228.

Broto, V. C., \& Bulkeley, H. (2013). Maintaining climate change experiments: Urban political ecology and the everyday reconfiguration of urban infrastructure. International Journal of Urban and Regional Research, 37(6), 1934-1948.

Buland, T. (1994). Framtiden er elektrisk. IFIM-notat, 4, 94. 
Bulkeley, H. A., Broto, V. C., \& Edwards, G. A. (2014). An urban politics of climate change: Experimentation and the governing of socio-technical transitions. Routledge.

Callon, M. (1984). Some elements of a sociology of translation: Domestication of the scallops and the fishermen of St Brieuc Bay. The Sociological Review, 32(1_ suppl), 196-233.

Canzler, W., Engels, F., Rogge, J. C., Simon, D., \& Wentland, A. (2017). From "living lab" to strategic action field: Bringing together energy, mobility, and information technology in Germany. Energy Research \& Social Science, $27,25-35$.

Cetina, K. K. (1995). Laboratory studies: The cultural approach to the study of science. In Handbook of science and technology studies (pp. 140-167). Los Angeles: Sage Publishing.

Christensen, T. H., Ascarza, A., \& Throndsen, W. (2013). Country-specific factors for the development of household smart grid solutions: Comparison of the electricity systems, energy policies and smart grid R\&D and demonstration projects in Spain, Norway and Denmark. IHSMAG Project report. Retrieved May 28, 2020, from https://vbn.aau.dk/ws/files/168269618/Christensen_ et_al._Country_specific_factors_2013.pdf.

Collantes, G., \& Sperling, D. (2008). The origin of California's zero emission vehicle mandate. Transportation Research Part A: Policy and Practice, 42(10), $1302-1313$.

Cotton, M., \& Devine-Wright, P. (2012). Making electricity networks "visible": Industry actor representations of "publics" and public engagement in infrastructure planning. Public Understanding of Science, 21(1), 17-35.

Curtis, M., Torriti, J., \& Smith, S. T. (2018). Demand side flexibility and responsiveness: Moving demand in time through technology. In Demanding energy (pp. 283-312). Cham: Palgrave Macmillan.

Engels, F., \& Münch, A. V. (2015). The micro smart grid as a materialised imaginary within the German energy transition. Energy Research \& Social Science, 9, 35-42.

ETIP SNET. (2018). Vision 2050: Integrating smart networks for the energy transition: Serving Society and Protecting the Environment. Retrieved March 22, 2020, from https://www.etip-snet.eu/wp-content/uploads/2018/06/ VISION2050-DIGITALupdated.pdf

European Commission (2020) Horizon 2020. Work Programme. Brussels. Accessed from: https://ec.europa.eu/research/participants/data/ref/ h2020/wp/2018-2020/main/h2020-wp1820-intro_en.pdf

Evans, J., \& Karvonen, A. (2011). Living laboratories for sustainability: Exploring the politics and epistemology of urban transition. In Cities and low carbon transitions (pp. 126-141). London: Routledge. 
Forlano, L. (2019). Cars and contemporary communications| Stabilizing/destabilizing the driverless city: Speculative futures and autonomous vehicles. International Journal of Communication, 13, 28.

Fosso, O. B., Molinas, M., Sand, K., \& Coldevin, G. H. (2014). Moving towards the smart grid: The Norwegian case. In 2014 International Power Electronics Conference (IPEC-Hiroshima 2014-ECCE ASIA) (pp. 1861-1867). IEEE.

Frantzeskaki, N., Borgström, S., Gorissen, L., Egermann, M., \& Ehnert, F. (2017). Nature-based solutions accelerating urban sustainability transitions in cities: Lessons from Dresden, Genk and Stockholm cities. In Nature-based solutions to climate change adaptation in urban areas (pp. 65-88). Cham: Springer.

Frøysnes, A. S. (2014). Bare en jevla boks?: en analyse av visjonsarbeidet knyttet til avanserte måle- og styringssystemer (AMS) (Master's thesis, NTNU)

Gangale, F., Vasiljevska, J., Covrig, C. F., Mengolini, A., \& Fulli, G. (2017). Smart grid projects outlook 2017. The Netherlands, Petten: Joint Research Centre of the European Commission.

Geels, F. W. (2002). Technological transitions as evolutionary reconfiguration processes: A multi-level perspective and a case-study. Research Policy, 31(8-9), 1257-1274.

Geels, F. W., \& Schot, J. (2007). Typology of sociotechnical transition pathways. Research Policy, 36(3), 399-417.

Goulden, M., Bedwell, B., Rennick-Egglestone, S., Rodden, T., \& Spence, A. (2014). Smart grids, smart users? The role of the user in demand side management. Energy Research \& Social Science, 2, 21-29.

Grydehøj, A., \& Kelman, I. (2017). The eco-island trap: Climate change mitigation and conspicuous sustainability. Area, 49(1), 106-113.

Haugland, B. T. (forthcoming) Self driving imaginaries, politics and innovation. Under review in Palgrave Communications.

Heidenreich, S. (2015). Sublime technology and object of fear: Offshore wind scientists assessing publics. Environment and Planning A, 47(5), 1047-1062.

Heiskanen, E., Hyvönen, K., Laakso, S., Laitila, P., Matschoss, K., \& Mikkonen, I. (2017). Adoption and use of low-carbon technologies: Lessons from 100 Finnish pilot studies, field experiments and demonstrations. Sustainability, $9(5), 847$.

Hess, D. J. (1997). Science studies. An advanced introduction. New York: New York University Press.

Hoogma, R. J., Kemp, R., Shot, J., \& Truffer, B. (2002). Experimenting for sustainable transport. The approach of strategic niche management. Spon Press: London and New York.

Jasanoff, S. (Ed.). (2004). States of knowledge: The co-production of science and the social order. Routledge.

Kårstein, A. (2008). HyNor-den norskebydrogenveien?: En studie av en storteknopolitisk bybrid (PhD Thesis, NTNU). 
Katzeff, C., \& Wangel, J. (2015). Social practices, households, and design in the smart grid. In ICT innovations for sustainability (pp. 351-365). Cham: Springer.

Kemp, R. (2005). Zero emission vehicle mandate in California: Misguided policy or example of enlightened leadership (pp. 169-191). UK, Cheltenham: Edward Elgar.

Köhler, J., Geels, F. W., Kern, F., Markard, J., Onsongo, E., Wieczorek, A., ... Fünfschilling, L. (2019). An agenda for sustainability transitions research: State of the art and future directions. Environmental Innovation and Societal Transitions, 31, 1-32.

Kohler, R. E. (2002). Place and practice in field biology. History of Science, $40(2), 189-210$.

Latour, B. (1987). Science in action: How to follow scientists and engineers through society. Harvard University Press.

Latour, B. (1993). The pasteurization of France. Harvard University Press.

Latour, B., \& Woolgar, S. (1979). Laboratory life: The construction of scientific facts. Princeton University Press.

Lorentzen, E., Haugneland, P., Bu, C., \& Hauge, E. (2017, October). Charging infrastructure experiences in Norway-the worlds most advanced EV market. In EVS30 Symposium (pp. 9-11)

Marres, N. (2013). Why political ontology must be experimentalized: On ecoshow homes as devices of participation. Social Studies of Science, 43(3), 417-443.

Marres, N. (2016). Material participation: Technology, the environment and everyday publics. Springer.

Michael, M. (2000). Futures of the present. In N. Brown, B. Rappert, \& A. Webster (Eds.), Contested futures (A sociology of prospective technoscience) (pp. 21-39). Aldershot: Ashgate.

Morozov, E., \& Bria, F. (2018). Rethinking the smart city. New York: Rosa Luxemburg Stiftung.

Naber, R., Raven, R., Kouw, M., \& Dassen, T. (2017). Scaling up sustainable energy innovations. Energy Policy, 110, 342-354.

Nahuis, R., \& Van Lente, H. (2008). Where are the politics? Perspectives on democracy and technology. Science, Technology, \& Human Values, $33(5), 559-581$.

Noel, L., de Rubens, G. Z., Sovacool, B. K., \& Kester, J. (2019). Fear and loathing of electric vehicles: The reactionary rhetoric of range anxiety. Energy Research \& Social Science, 48, 96-107.

Papazu, I. (2016). Authoring participation. Nordic Journal of Science and Technology Studies, 4(1), 17-31.

Papazu, I. (2018). Storifying Samsø's renewable energy transition. Science As Culture, 27(2), 198-220. 
Park, S. (2011). Iceland's hydrogen energy policy development (1998-2007) from a sociotechnical experiment viewpoint. International Journal of Hydrogen Energy, 36(17), 10443-10454.

Penna, C. C., \& Geels, F. W. (2015). Climate change and the slow reorientation of the American car industry (1979-2012): An application and extension of the Dialectic Issue LifeCycle (DILC) model. Research Policy, 44(5), 1029-1048.

Pinch, T. J., \& Bijker, W. E. (1984). The social construction of facts and artefacts: Or how the sociology of science and the sociology of technology might benefit each other. Social Studies of Science, 14(3), 399-441.

Rosa, H. (2013). Social acceleration: A new theory of modernity. Columbia University Press.

Rosenow, J., \& Kern, F. (2017). EU energy innovation policy: The curious case of energy efficiency. In Research handbook on EU energy law and policy. Edward Elgar Publishing.

Rosol, M., Béal, V., \& Mössner, S. (2017). Greenest cities? The (post-) politics of new urban environmental regimes. Environment and Planning A: Economy and Space, 49(8), 1710-1718.

Ryghaug, M., \& Sørensen, K. H. (2009). How energy efficiency fails in the building industry. Energy Policy, 37(3), 984-991.

Ryghaug, M., \& Toftaker, M. (2016). Creating transitions to electric road transport in Norway: The role of user imaginaries. Energy Research \& Social Science, $17,119-126$.

Ryghaug, M., \& Skjølsvold, T. M. (2019). Nurturing a regime shift toward electro-mobility in Norway. In The Governance of Smart Transportation Systems (pp. 147-165). Cham: Springer.

Ryghaug, M., Skjølsvold, T. M., \& Heidenreich, S. (2018). Creating energy citizenship through material participation. Social Studies of Science, 48(2), 283-303.

Ryghaug, M., Ornetzeder, M., Skjølsvold, T. M., \& Throndsen, W. (2019). The role of experiments and demonstration projects in efforts of upscaling: an analysis of two projects attempting to reconfigure production and consumption in energy and mobility. Sustainability, 11(20), 5771.

Sadowski, J., \& Levenda, A. M. (2020). The anti-politics of smart energy regimes. Political Geography, 81, 102202.

Schot, J., \& Steinmueller, W. E. (2018). Three frames for innovation policy: R\&D, systems of innovation and transformative change. Research Policy, 47(9), $1554-1567$.

Silvast, A., Williams, R., Hyysalo, S., Rommetveit, K., \& Raab, C. (2018). Who 'uses' smart grids? The evolving nature of user representations in layered infrastructures. Sustainability, 10(10), 3738.

Skjølsvold, T. M. (2014). Back to the futures: Retrospecting the prospects of smart grid technology. Futures, 63, 26-36. 
Skjølsvold, T. M., \& Ryghaug, M. (2015). Embedding smart energy technology in built environments: A comparative study of four smart grid demonstration projects. Indoor and Built Environment, 24(7), 878-890.

Skjølsvold, T. M., \& Ryghaug, M. (2020). Temporal echoes and cross-geography policy effects: Multiple levels of transition governance and the electric vehicle breakthrough. Environmental Innovation and Societal Transitions, 35, 232-240.

Skjølsvold, T. M., Ryghaug, M., \& Berker, T. (2015). A traveler's guide to smart grids and the social sciences. Energy Research or Social Science, 9, 1-8.

Skjølsvold, T. M., Ryghaug, M., \& Throndsen, W. (2020). European island imaginaries: Examining the actors, innovations, and renewable energy transitions of 8 islands. Energy Research \& Social Science, 65, 101491.

Solbu, G. (2018). The physiology of imagined publics. Science \& Technology Studies, 31, 39-54.

Sørensen, K. H. (2004). Cultural politics of technology: combining critical and constructive interventions?. Science, technology, \& human values, 29(2), 184-190.

Sørensen, K. H. (2013). Beyond innovation. Towards an extended framework for analysing technology policy. Nordic Journal of Science and Technology Studies, $1(1), 12-23$.

Sørensen, K. H., Lagesen, V. A., \& Hojem, T. S. M. (2018). Articulations of mundane transition work among consulting engineers. Environmental Innovation and Societal Transitions, 28, 70-78.

Strengers, Y. (2013). Smart energy technologies in everyday life: Smart Utopia?. Cham: Springer.

Strengers, Y. (2014). Smart energy in everyday life: are you designing for resource man?. Interactions, 21(4), 24-31.

Throndsen, W. (2017). What do experts talk about when they talk about users? Expectations and imagined users in the smart grid. Energy Efficiency, $10(2), 283-297$.

Tøndel, G., \& Seibt, D. (2019). Governing the elderly body: Technocare policy and industrial promises of freedom. In Digitalization in industry (pp. 233-259). Cham: Palgrave Macmillan.

Vesnic-Alujevic, L., Breitegger, M., \& Pereira, A. G. (2016). What smart grids tell about innovation narratives in the European Union: Hopes, imaginaries and policy. Energy Research \& Social Science, 12, 16-26.

Von Wirth, T., Fuenfschilling, L., Frantzeskaki, N., \& Coenen, L. (2019). Impacts of urban living labs on sustainability transitions: Mechanisms and strategies for systemic change through experimentation. European Planning Studies, $27(2), 229-257$.

Williams, R., \& Edge, D. (1996). The social shaping of technology. Research Policy, 25(6), 865-899.

Winner, L. (1980). Do artifacts have politics? Daedalus, 109, 121-136. 
Open Access This chapter is licensed under the terms of the Creative Commons Attribution 4.0 International License (http://creativecommons.org/licenses/ by $/ 4.0 /$ ), which permits use, sharing, adaptation, distribution and reproduction in any medium or format, as long as you give appropriate credit to the original author(s) and the source, provide a link to the Creative Commons licence and indicate if changes were made.

The images or other third party material in this chapter are included in the chapter's Creative Commons licence, unless indicated otherwise in a credit line to the material. If material is not included in the chapter's Creative Commons licence and your intended use is not permitted by statutory regulation or exceeds the permitted use, you will need to obtain permission directly from the copyright holder. 